\title{
肺癌術後照射結果の検討
}

\section{Postoperative Radiation Therapy for Lung Cancer}

築山 嚴・筧 正兄・柳川繁雄・影本正之・片岡正明

北川俊夫・米山武志・宮沢直人・斎藤明男 *

要旨：国立がんセンターにおいて，過去13年間に術後照射が行われた145肺癌症例の治療成績を 検討した結果，この方法による肺癌治療成績の向上を計るためには，照射局所の再発率 を減少させるべき照射技術の改善, すなわち，更に有効性の高い照射方法，精度の高い 残存病巣の検出法等の開発, 並びに局所照射後遺症の発現防止に努力を拂うべき必要性 が指摘された。そしてこれら要求に応じて現在迄に試みられて来た $2 \sim 3$ の研究を紹介 した。

\section{はじめに}

根治切除を期待して施行された肺癌の手術に 際して, 腫瘍の重要藏器への侵襲，技術的制約 等の理由により, 主病巣切除後なお局所に微少 病巣の残存を余儀なくされた症例, 又は視診, 触診にて把握し得る病巣切除が遂行された後, 腫瘍の病態, 局所進行度等から判断して, 術野 に不可視微少病巣の残存が強く推定された症例 に対して, 手術成績の向上を計るための最も合 理的かつ有効な治療手段の 1 つとして, 放射線 の術後照射が広く用いられてきた。すなわち放 射線療法が従来頭頸部領域, 皮虐, 子宮等諸藏 器癌の治療において示してきた優れた成績から 考えられるその高い有効性と, 癌組織に選択的 に認められる治療効果の特殊性に基づいて, 放 射線照射による上記残存病巣の根絶を期待した ものである。

しかし年ら，現在までにこの治療法による 成績について検討された数多くの結果には必ら

国立がんセンター

* 国立函館病院
ずしも十分満足すべき成績の向上が認められず， この治療法適用に際しての照射技術をはじめ数 多い因子の改善, 充実が要求されてきた。

そこで本研究においては，この方法によって 治療された症例の臨床結果を, 主として治療技 術の改善を目標として分析，検討を試みたので, その結果を報告する。 又それら結果に基づいて 開発した 2 〜の治療技術を紹介する.

\section{I . 術後照射結果の検討}

1. 研究方法

\section{A. 材料}

肺癌の術後照射結果は, 他臓器のそれと同様, 手術術式，放射線照射法等数多くの因子によっ て影響されることから，その差異を可及的少な く止めるため本研究における検討材料は, 同一 施設においてほぼ等しい手術術式，照射方法に よって治療された症例群の治療結果に限定した。 すなわち，1962年から1979年までの期間に，国 立がんセンターにおいて根治目的で手術が施行 され, なお術野に微少病巣が残存した肺原発癌, 
表 1 照射対象別症例分布

\begin{tabular}{llc}
\hline \multicolumn{1}{c}{ 症例群 } & \multicolumn{1}{c}{ 照射対象 } & 症例数 \\
\hline 術時残存病巣 & 原発部位残存病巣 & 27 \\
照射症例群 & リンパ節転移 & 20 \\
& 切除断端残存病巣 & 29 \\
& その他 & 14 \\
& 計 & 90
\end{tabular}

予防照射症例群 55

総 計 145

STAGE I , II , III 症例のうち, 上記部位に対して 3000rad以上の線量が計画に基づいて照射し得た 145例が用いられた。

これら症例の群別構成はつぎの如くである。

イ）照射対象別分布

照射対象となった病巣によって症例を群別す ると表 1 の如くである。

i ) 術時残存病巣照射症例群

術野に明らかな腫瘍組織の残存を認め, これ らに対し術後照射を行った90例を術時残存病巣 照射症例群とした。なおこれら症例はその残存 腫瘍組織の大きさが原発部位, 切除断端の病巣 は $2 \mathrm{~mm}$ 厚以下の微少容積のもの, 又残存リンパ 節は，0.5〜2.0cm径の大きさのものに限定し， 過大容積の病巣が残存した症例は本検討対象よ り除外した。これは過大容積の病巣は放射線照 射による根絶を期待し難いからである。

ii）予防照射症例群

術野における可視, 触の病巣が切除されたの ち, 病巣の進展度, 臨床経過, 腫瘍の性状等か ら, なお術野に不可視微少病巣の残存が強く推 定されたため, 再発を予防する目的で放射線照 射が施行された55例を予防照射症例群として， 前者と区別して検討した。

口）臨床病期別分布

前記各群症例の病期別分布は表 2 の如くであ ク, STAGE IIIの症例が各症例群のうち夫々 85.5 $\%, 89 \%$ を占め, 早期症例は比較的少ない.

八) 組織像別分布

腫瘍の組織像による症例の分布は, 表 3 のご とくであり, 腺癌が 62 例で最も多く, 扁平上皮
表 2 臨床病期別症例分布

\begin{tabular}{|c|c|c|c|}
\hline $\begin{array}{c}\text { 臨床病期 } \\
\text { (StAGE) }\end{array}$ & \begin{tabular}{l}
\multicolumn{1}{c}{ 症 例 } \\
術時残存病巣 \\
照射症例群
\end{tabular} & $\begin{array}{l}\text { 数 } \\
\text { 予防照射 } \\
\text { 症例群 }\end{array}$ & 計 \\
\hline I & 11 & 5 & 16 \\
\hline II & 2 & 1 & 3 \\
\hline III & 77 & 49 & 126 \\
\hline 計 & 90 & 55 & 145 \\
\hline
\end{tabular}

表 3 組織像別症例分布

\begin{tabular}{cc}
\hline 組織像 & 症例数 \\
\hline 腺癌 & 62 \\
扁平上皮癌 & 59 \\
大細胞癌 & 12 \\
小細胞癌 & 2 \\
末分化癌 & 2 \\
その他 & 8 \\
\hline 計 & 145 \\
\hline
\end{tabular}

癌が59例とこれに次ぎ, その他のものは前 2 者 に比し少ない。ただし表中に認められる症例数 の差異はここに検討材料として用いられた症 例が, 前述の如き諸条件に従って選択されたも のであることから, 必らずしも組織像と病巣残 存度の関係を示すものではない.

二）年令別分布

本研究に用いられた症例の年令は, Fig.1のご とく，50～70才の年令層に最も大きい分布を示 している。

\section{B. 治療}

\section{イ）手術}

個々の症例に応じて病巣を含む肺組織の切除 並びに, 縦隔洞リンパ節の廓清又は摘出が施行 された。

口）放射線療法

術時病巣残存症例に対しては, 主として $6 \mathrm{M}$ $\mathrm{VX}$ 線又は ${ }^{60} \mathrm{Co} r$ 線を用いた前後対向 2 門照射法 により, 病巣残存部位に3000～7000 rad/ 3〜 7 週，上縦隔には必要に応じて5000 rad/ 5 週が照 射された。

また予防照射症例に対しては, 病巣残存が推 
Fig. 1. Case distribution

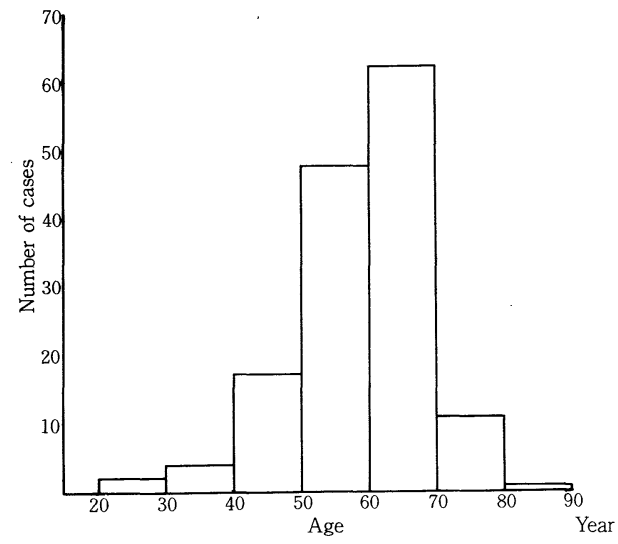

定された上縦隔に $5000 \mathrm{rad} / 5$ 週が与えられた。 なお手術後照射開始迄の待期期間は, 夫々の症 例の術後経過によって異なるが, 全例中 120 例に 対しては, 術後30日以内に照射が開始されてい る.

八）化学療法

全例中98例には症例の臨床経過に応じて放射 線照射前, 照射期間中, 照射終了後等の時期に 化学療法の併用が試みられた。

\section{2. 研究結果並びに検討}

以上の如く治療され, 設定した諸条件に従っ て選択された症例の治療結果を分析並びに検討 した結果は次の如くである。

\section{1）遠隔成績}

i ) 術時残存病巣照射症例群, 予防照射症例 群, 夫々の治療後生存傾向はFig.2に示すごとく であり, 各症例群の 5 年生存率は夫々, $14.2 \%$, $17.7 \%$ で, 両者の間に著るしい差異は認められ ず，またその成績は，なお既報告のものと同様 十分満足されるものとは考之られない.

ii ) 腫瘍の組織像別 5 年生存率を, 比較的症 例数が多い腺癌, 扁平上皮癌について検討した 結果, 腺癌は $9.2 \%$, 扁平上皮癌は $21.4 \%$ で腺癌 は扁平上皮癌症例に比して低い值を示していた。

これは, 本症例群において腺癌の遠隔転移発 現率 $(73.2 \%)$ が扁平上皮癌のそれ $(51 \%)$ に比し て高いことによるものと考えられた。

以上の結果から, 術後照射の治療成績は, 腫
Fig. 2. Survival of cases with postoperative irradiation.

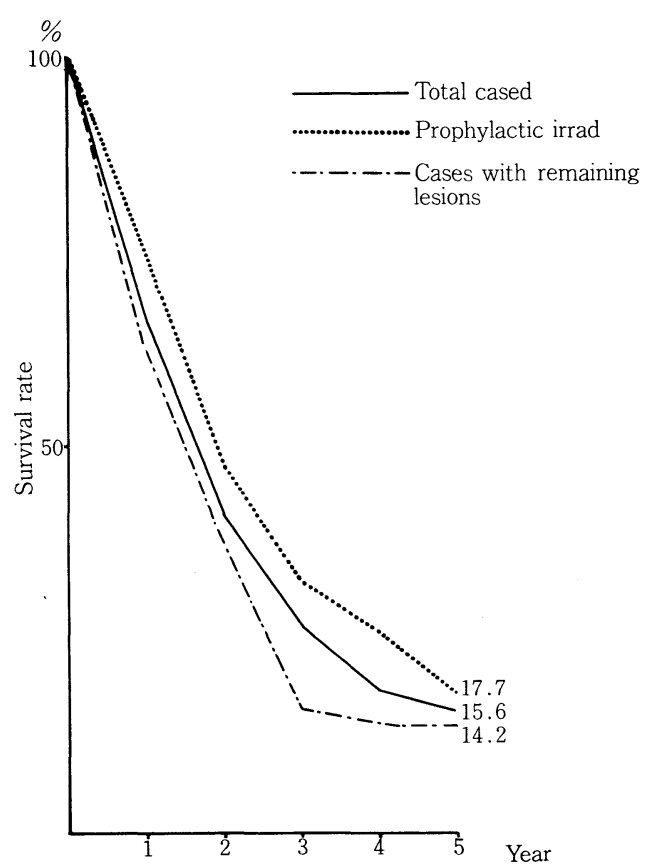

瘍の組織学的性状に影響される可能性があると 考えられる.

iii ）臨床病期別生存率に関しては, 全症例の 80\%以上がSTAGE III の臨床病期にあることから， 各 STAGE 症例群相互の比較は困難である。しか し比較的症例数の多い腺癌, 扁平上皮癌夫々の STAGE III 症例の 5 年生存率は, 夫々 $9.8 \%, 12.1$ \%を示していたことからこれらの值と組織像 別全病期総合生存率との相互比較から, 術後照 射の治療成績はその多くを占める進行症例の治 療結果に影響されていると考えられた。したが つて今後進行症例 (STAGE III) の治療成績向上を 計ることにより, 術後照射の成績は改善される ものと思われる。

\section{2 ) 死亡原因}

上記生存率の検討において, 術後照射を施行 された症例がなお多く死亡していることから， 生存率に影響を与えたこれら症例死亡の原因に ついて検討を行った。

123死亡症例数を死因について分別した結果は 表 4 の如くであり，その $21.1 \%(26 / 123)$ は局所 
表 4 術後照射症例 (St. I ～III ) 死亡原因

\begin{tabular}{lrr}
\hline \multicolumn{1}{c}{ 死亡原因 } & 症例数 & \multicolumn{1}{c}{$\%$} \\
\hline 局所再発 & 26 & 21.1 \\
局所再発十遠隔転移 & 11 & 8.9 \\
遠隔転移 & 60 & 48.7 \\
他病 & 5 & 4.0 \\
不明 & 21 & 17.0 \\
\hline \multicolumn{1}{c}{ 計 } & 123 \\
\hline
\end{tabular}

表 6 照射線量と局所制御率

\begin{tabular}{ccc}
\hline 線量 $(\mathrm{rad})$ & \multicolumn{2}{c}{ 局所制御率 $\%$} \\
\hline $3000 \sim 3999$ & 83.3 & $(5 / 6)$ \\
$4000 \sim 4999$ & 64.2 & $(9 / 14)$ \\
$5000 \sim 5999$ & 53.3 & $(8 / 15)$ \\
$6000 \sim$ & 60.0 & $(3 / 5)$ \\
\hline
\end{tabular}

再発, $48.7 \%(60 / 123)$ は遠隔転移により死亡し, その他の原因による死亡は比較的少ない。した がって上記 2 原因が主としてこの治療の成績に 影響を与えたものと考えられる。しかし乍ら， 放射線療法の治療成績に対する貢献は, この治 療法の特性上照射局所のみに限定されることか ら, 本論文では以後主として, 照射対象となっ た病巣の局所制御について検討することにする.

\section{3) 局所制御率}

先に示された局所再発は，術後照射の不成功， すなわち放射線照射による局所制御が得られな かったことに起因する可能性が大きいと考之ら れることから，これら症例の治療に適用された 従来の照射法による局所制御を術時病巣残存症 例群において照射終了 1 个月後局所病巣の残存, 再発の有無から判断，検討した。これは，放射 線照射の効果は完了するまでに少なくとも 3 週 間は要することが経験されて来たからである。 その結果は表 5 の如く, 各照射対象の局所制御 率は, 比較的低い值を示し, 各対象相互間には 明らかな差異は認められなかった。

また，腫瘍の組織学的性状の違いによる局所 制御率に関しては，腺癌，扁平上皮癌について 検討した結果，37.5\%(9/24)，46\%(16/35)と 本検討材料に関しては, 両者の間に有意差は認
表 5 照射対象別局所制御率

\begin{tabular}{cc}
\hline \multicolumn{1}{c}{ 対 象 } & 制御率 $(\%)$ \\
\hline 原発部位残存病巣 & $38.0(8 / 21)$ \\
リンパ節転移 & $50.0(7 / 14)$ \\
切除断端残存病巣 & $43.4(10 / 23)$ \\
\hline
\end{tabular}

表 7 照射後遺症

\begin{tabular}{lcc}
\hline \multicolumn{1}{c}{ 症状 } & 線量 $(\mathrm{rad})$ & 年令 \\
\hline 上肢痛 & 6000 & 59 \\
気管狭窄 & 6500 & 38 \\
喀痰 & 4850 & 65 \\
胸痛, 咳 & 5985 & 56 \\
息切れ & 5000 & 65 \\
下肢知覚異常 & 5200 & 65 \\
呼吸困難 & 6000 & 57 \\
下肢知覚異常 & 4000 & 57 \\
気管狭窄 & 7000 & 41 \\
下肢知覚異常 & 5000 & 65 \\
\hline
\end{tabular}

められなかった。この結果については症例数の 増加を待って更に詳細に検討する予定である。

以上示された局所制御率は，決して満足され るべきものではなく，照射技術の改善によって 局所制御率を向上せしめることが，術後照射成 績向上を計るための大きい因子であると考えら れる。

\section{4 ）照射線量と局所制御率との関係}

以上の結果から，放射線療法においてその局 所制御率に最も大きく関与する因子の1つであ る照射線量について更に検討を試みた。その結 果は，表 6 に示すごとく，本検討に用いられた 材料に関しては，照射線量と局所制御率の間に は明らかな関係を見出し得なかった。

\section{5 ）照射後遺症に関する検討}

開胸手術により大きい侵襲を与えられた局所 に，更に放射線照射を付加するに当っては，そ の照射による後遺症が手術単独又は，放射線単 独療法に比して多く発現する可能性が考えられ， その後遺症が治療成果に与える影響も無視し得 ない。そこで局所制御し得たと判断された症例 のうち，その後の臨床経過観察によって，放射 
Fig. 3. Survival of cases with postoperative irradiation

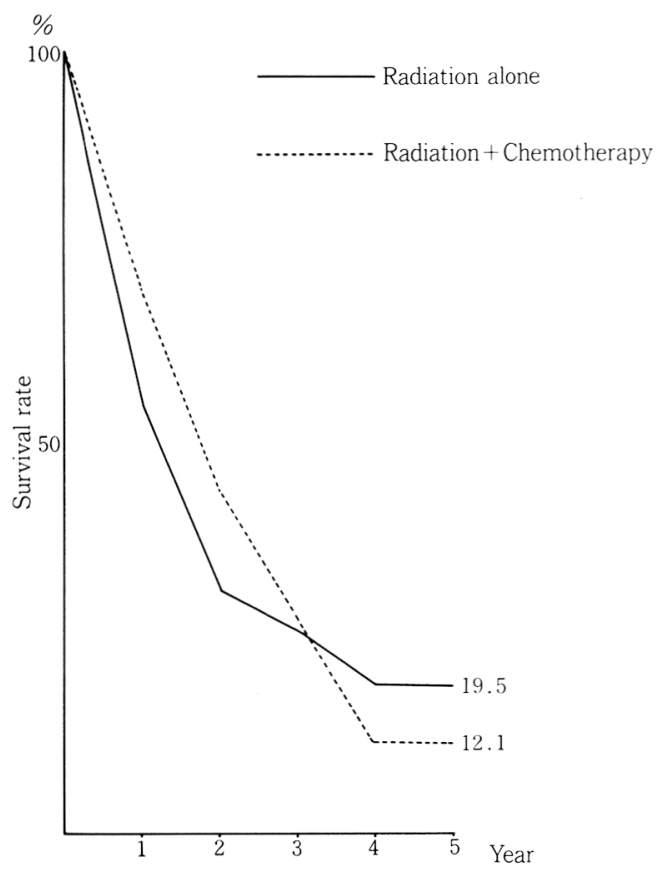

線照射後遺症と判断される所見を呈した10例に ついて検討した結果は表 7 であり,これら症例 の多くは50才以上の年令で, 又5000 rad以上の線 量が与えられていることから，上記年令の症例 に5000 rad以上の線量が与えられていることから， 上記年令の症例に5000rad以上の照射を行なうに 際しては, 後遺症発現に対しての配慮が必要と 考えられた。

又以上の結果から，後遺症発現を少なく止め るためには，5000rad以上の線量の照射は避ける ことが望ましい.そして尚, 治療成績の向上を 計るためには，5000rad以下の線量で一層高い局 所制御率を獲得し得る照射技術の改善，開発が 必要と考えられた。

\section{II 。治療成績改善に関する試み}

以上述べた肺癌術後治療結果の検討に基づき, その成績向上を計るため試みられて来た 2,3 の治療手段について述べる.

\section{I. 化学療法の併用}

化学療法は，放射線照射との併用による局所
表 8 化学療法併用と局所制御率

$\begin{array}{lll}\text { 放射線単独 } & 62.1 \% & (23 / 37) \\ \text { 放射線照射+化学療法 } & 50.0 \% & (3 / 6)\end{array}$

Fig. 4. Semiconductor radiation detector for local diagnosis of remaining lesions in the bronchial wall

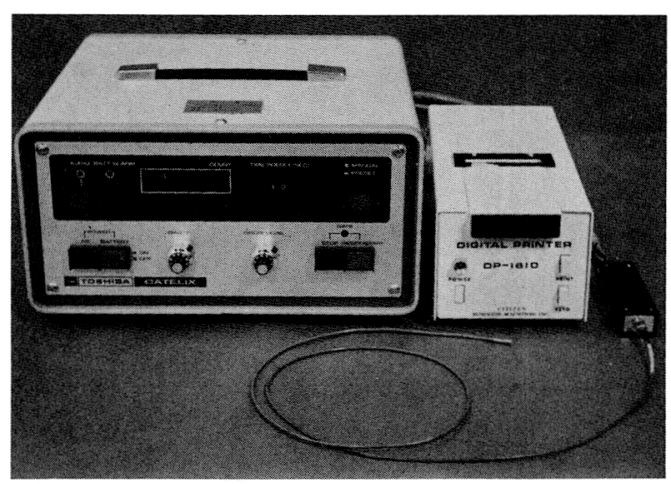

治療効果の改善と同時に，潜在転移制御による 生存率向上を期待して試みられた。

その結果はFig.3に示す如く化学療法併用によ る明らかな遠隔成績の改善は認められなかった。

又表 8 に示すごとく，照射期間中併用された 化学療法による局所制御率の明らかな改善を示 されていない。

以上の如く，従来の使用方法による化学療法 の併用においては, 治療成績の改善は得られて いないが, 前述の如く, 化学療法は遠隔転移の 制御に最も合理的な手段の 1 つと考えられるこ とから, 今後のこの治療法の進歩が望まれる.

\section{2. 局所診断技術の改善}

従来施行されて来た外部照射法による術後照 射野の設定は, 術時所見と, 術時病巣部位に残 した印に基づいて体外より照射範囲を想定して 行なわれた。しかし乍ら，気管支切除断端にお ける残存病巣の多くは, その存在が術後切除標 本の鏡検結果から診断されたものであったため， その病巣の範囲, 深達度は必らずしも高い精度 では把握されず，安全性を考慮して，想定され た病巣面積より広い照射野が設定，照射される 事が多かった。したがって，照射対象となる病 巣の把握精度の向上により，ょり病巣に限局し 
Fig. 5. Semiconductor radiation detector inserted in the bronchial stump

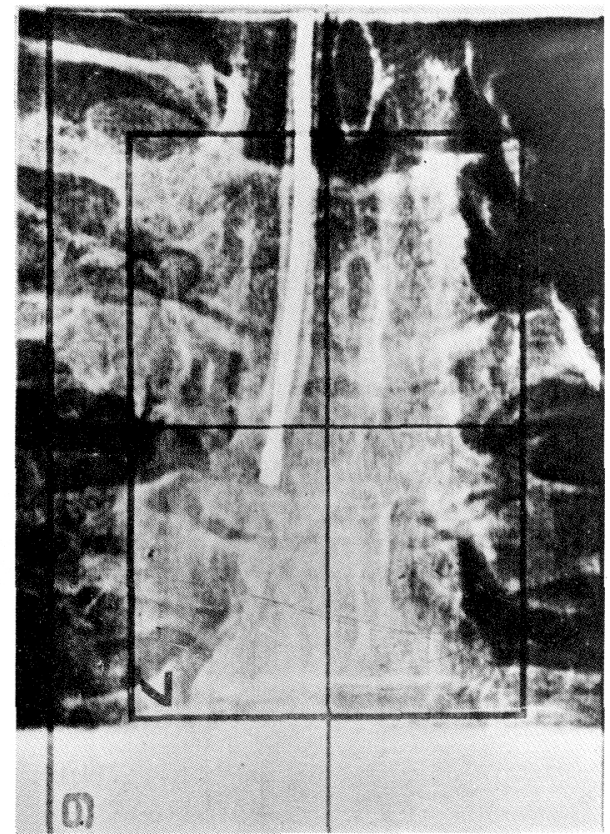

た小さい照射野で，大きい線量の投与が可能々 なり，同時に後遺症の発現も減少すると考えら れる。

著者等は加加る切除断端残存病巣の存否, 範 囲を更に高い精度で把握する手段として, Fig.4 の如き装置を開発した。これは，従来食道等管 腔藏器における, がん病巣の早期診断の目的に 用いられて来た半導体検出器の検出能, 計数機 能を改善したもので，投与され，一定時間後組 織内に残留するRIの放射能計数值の差異により, がん病巣を周辺健常組織から判別し得る機能, すなわち微少残存病巣検出の可能性が基礎奏験 により証明され，な扔臨床試用(Fig.5)の結果, 表 9 に示すごとく 1 例を除いて T/N比(腫瘍組織 と健常組織における計数值の比)が示した 1.45 以 上の値に基づき, この装置は前記微少病巣検出 の目的に適用し得る可能性が大きいと考えられ ている。

\section{AFTERLOADING小線源照射法の開発}

従来用い放て来た外部照射法は, 病巣周辺 健常臓器の放射線被曝を十分回避することが困 難であったことから，照射後遺症発現の原因と
表 9 半導体檢出器による测定結果

$\mathrm{RI}:{ }^{32} \mathrm{P} \quad 300 \mu \mathrm{Ci}$

测定時：RI投与後48時間

\begin{tabular}{ccc}
\hline 病巣 & 組織像 & $\mathrm{T} / \mathrm{N}$ \\
\hline 放治後再発 & 扁平上皮癌 & 1.97 \\
同上 & 同上 & 1.60 \\
同上 & 同上 & 1.51 \\
切除断端再発 & 同上 & 5.51 \\
同上 & 腺癌 & 1.25 \\
\hline
\end{tabular}

もなり，前述の如く5000rad以上の線量投与が困 難な場合も経験されて来た。

又，先に局所制御率に示された如く，従来の 放射線による外部照射の局所照射効果はな技満 足されるものではない。

そこで著者等は, 線量分布が病巣に極めて限 局性であり，又，外部照射法に比して高い照射 効果が期待し得る小線源照射法をAFTERLOADING 技術を導入して，この治療に適用を試みている。

Fig.6はその一例であり，6 MVX線，中性子線 の外部照射後再発した腺癌病巣に対し，左上肺 葉切除を施行した後，なお胸壁に残存した原発 病巣に, 術時線源誘導管を病巣部に固定し, そ

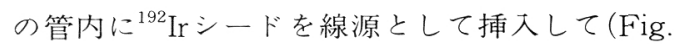
7 )6000radを局所に限局して照射した。この症 例は 2 年以上経過した現在，な扔局所に再発又 は照射後遺症の発現を認めていない。

したがって，この方法は有效性の高い術後照 射法の 1 つして導入され，現在更に多くの症 例に対して試みられている。

\section{おわりに}

以上述べた如く, 肺癌の微少残存病巣に対す る術後照射成績について検討した結果には，長 期生存率，局所制御率共に満足すべき成果は得 られなかったことから，今後，この治療法に上 る肺癌治療成績の向上を計るためには，局所治 療手段である放射線療法としては，特に照射局 所の再発率減少に努力が払われるべきであると 考之られた。

そして，功改善遂行に当っては，更に有 
Fig. 6. Recurrent adenocarcinoma of the lung after external radiation treatment

a Before therapy

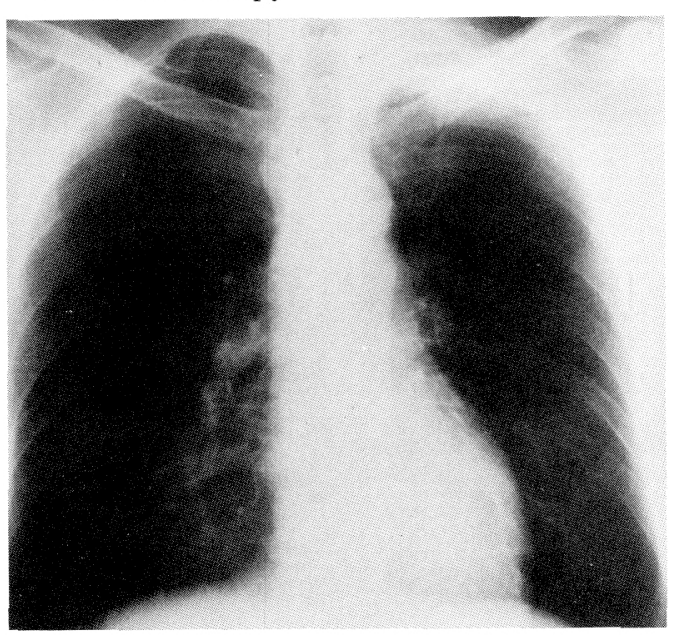

\section{Fig. 7.}

a The guide tubes fixed on the remaining lesion in the chest wall.

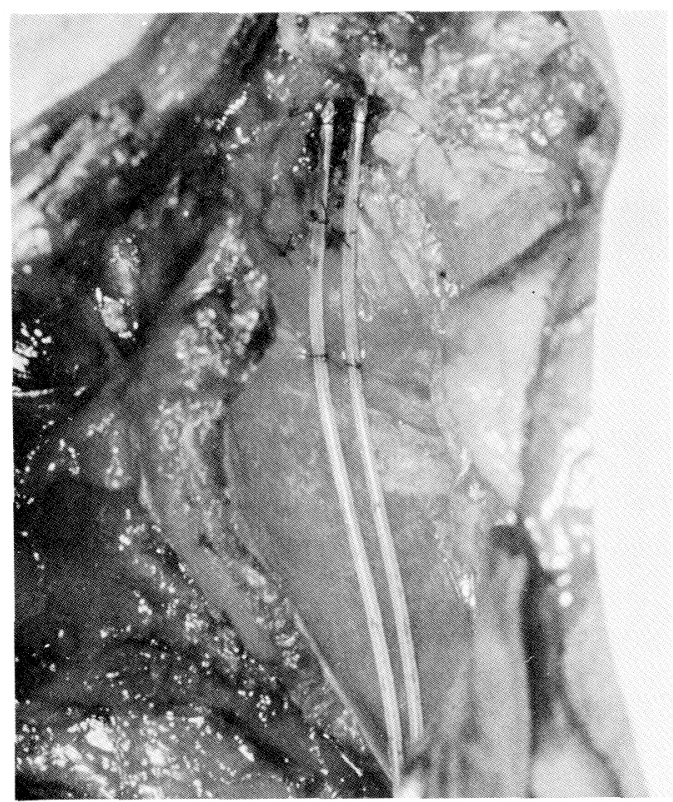

効性の高い照射方法, 精度の高い残存病巣の把 握方法等の技術的開発が要求され, これら開発 は, 放射線独自の技術的開発の外に，手術，内 視鏡等他診療技術との共同作業も重視されねば ならないと考える。

\section{b 1 week after upper lobectomy}

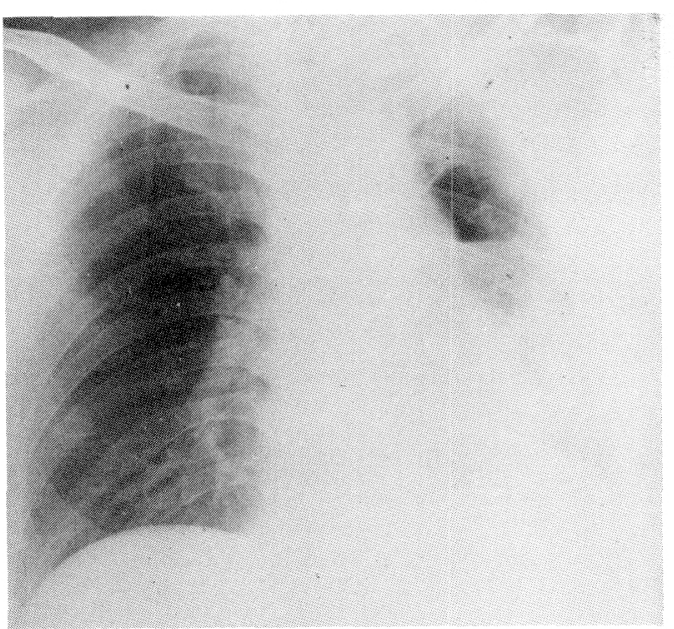

b X-ray film of radiation sources loaded in the guide tubes.

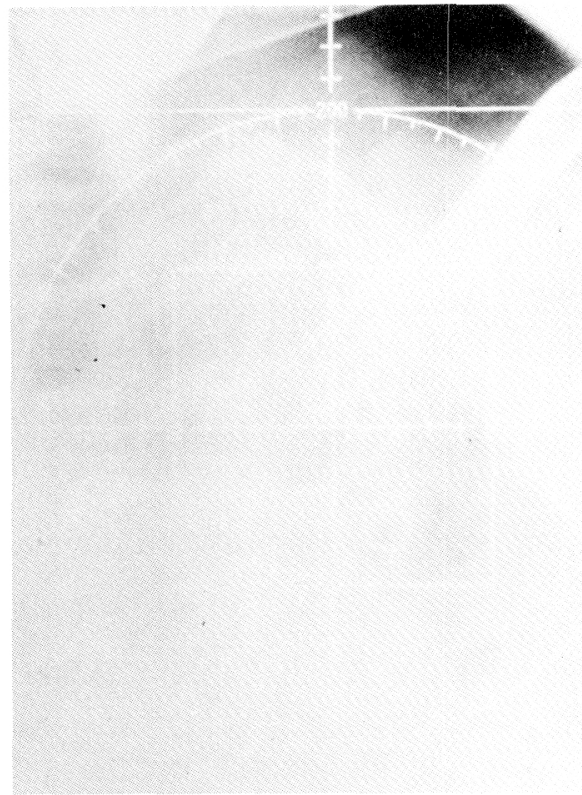

本論文においては，上記の考之方に従って著 者等が試みて来た $2 ， 30$ 万法を紹介したが, その他近来開発されつつある加速粒子線照射の 導大による照射効果の向上も期待されている。 
文

1) Green, N. et al.: Postresection irradiation for primary lung cancer. Therapeutic Radiology, 116:405-407, 1975 .

2) Choi, N. C. H. et al.: Basis for new strategies in postoperative radiotherapy of bronchogenic carcinoma. Int. J. Rad. Oncology., 6:31-35, 1980.

3) Houtte, P. V. et al.: Postoperative radiation therapy in lung cancer. Radiation Oncology., $6: 983-986,1980$.

5) 小田野幾雄 : 肺癌術後予防照射の必要性の検討. 日医放会誌，39：840-847，1979.

6) Hilaris, B. S., Martini, N.:Inrerstitial brachytherapy in cancer of the lung. Int. J. Rad. Oncol., $5: 1951-1956,1979$.

7）北川俊夫：開創小線源組織内照射法. 癌と化学 療法, 7:1746-1752, 1980 .

8）上田英雄, 飯尾正宏：IN VIVO $\beta$ メトリーによる 診断法「核医学臨床生理診断法」医歯薬出版, $321-347,1971$.

4) 竹川佳宏：肺癌の術前照射及び術後照射の検討.

日医放会誌，37：768-777，1977. 


\title{
Postoperative Radiation Therapy for Lung Cancer
}

\author{
Iwao Tsukiyama, Masae Kakehi, Shigeo Yanagawa, \\ Masayuki Kagemoto, Masaaki Kataoka, Toshio Kitagawa, \\ Takeshi Yoneyama, Naoto Miyazawa, and Akio Saito*
}

\author{
National Cancer Center \\ * National Hakodate Hospital
}

\begin{abstract}
In order to improve the clinical results of postoperative radiation therapy for lung cancer, the clinical results of 145 stage I-III lung cancer cases receiving external high energy radiation treatment of more than 3000 rad to remaining lesions post-operatively at the National Cancer Center in Tokyo during the last 15 years were investigated. The 5 year survival rate of the cases were $15.6 \%$ while in $21.1 \%$ and $48.7 \%$ the main cause of death was local failure and distant metastases, respectively. Most cases developing postradiation complications were over 50 years old and had more than 5000 rad irradiation.

According to these results, develpment of more effective, more selective and more reasonable irradiation techniques and more precise local diagnostic procedure are necessary in postoperative radiotherapy to obtain a better local control rate.

In this paper, recently developed treatment postoperative radiotherapy techniques were also introduced, i.e. irradiation combined with chemotherapy, intraoperative applications of afterloading small source irradiation technique with ${ }^{192}$ Ir seeds to irradiate small remaining lesions in the chest cavity and a semi-conductor radiation detector for detection of remaining lesions in the bronchial stump after resection of the lung using ${ }^{32} \mathrm{P}$.
\end{abstract}

